\title{
Origin and function of circulating plasmablasts during acute viral infections
}

\section{Katja Fink *}

Singapore Immunology Network, Agency for Science, Technology and Research A*STAR, Singapore

Edited by:

Ignacio Sanz, University of Rochester, USA

\section{Reviewed by:}

Martin Bachmann, Cytos

Biotechnology, Switzerland

Jose A. Brieva, University of Cadiz,

Spain

Frances E. Lee, University of

Rochester Medical Center, USA

*Correspondence:

Katja Fink, Singapore Immunology Network, Agency for Science,

Technology and Research, $8 \mathrm{~A}$

Biomedical Grove, 04-01 Immunos,

Singapore 138648.

e-mail:katja_fink@immunol.a-star.

edu.sg
Activated B cells proliferate and differentiate into antibody-producing cells, long-lived plasma cells, and memory B cells after immunization or infection. Repeated encounter of the same antigen triggers the rapid re-activation of pre-existing specific memory B cells, which then potentially enter new germinal center reactions and differentiate into short-lived plasmablasts or remain in the system as memory B cells. Short-lived class-switched IgG and IgA plasmablasts appear in the circulation transiently and the frequency of these cells can be remarkably high. The specificities and affinities of single plasmablasts in humans have been reported for several viral infections, so far most extensively for influenza and HIV. In general, the immunoglobulin variable regions of plasmablasts are highly mutated and diverse, suggesting that plasmablasts are derived from memory B cells, yet it is unclear which memory B cell subsets are activated and whether activated memory B cells adapt or mature before differentiation. This review summarizes what is known about the phenotype and the origin of human plasmablasts in the context of viral infections and whether these cells can be predictors of long-lived immunity.

Keywords: plasmablast, memory B cells, virus, dengue, antibodies

\section{PHENOTYPE OF INFECTION-INDUCED HUMAN PLASMABLASTS IN THE BLOOD}

Several studies have analyzed the kinetics and phenotypic changes of $\mathrm{B}$ cells in the blood of vaccinated or infected individuals by flow cytometry. Differentiation into plasmablasts $(\mathrm{PB})$ is most commonly monitored with surface markers CD19, CD20, CD27, CD38, and CD138 and intracellular marker Ki-67 (Table 1). CD38 catalyzes the formation of cyclic ADP-ribose and NADP and regulates $\mathrm{Ca}^{+}$signals in lymphoid cell (Partida-Sanchez et al., 2001). CD27, a member of the TNF receptor family that induces differentiation and promotes survival (Borst et al., 2005), is expressed on the majority of memory B cells (Wu et al., 2011) and is highly up-regulated on plasmablasts (Qian et al., 2010). CD20 is down-regulated when blood-derived memory $\mathrm{B}$ cells differentiate into plasmablasts (Jego et al., 2001). Plasmablasts proliferate extensively, evident by the intracellular expression of proliferationassociated protein Ki-67 (its function is unclear; Wrammert et al., 2008; Qian et al., 2010). When human PBMC are differentiated in vitro with IL-6, syndecan-1 (CD138) is acquired as a marker of plasma cells (PC; Jego et al., 2001). This is similar in mouse studies where CD138 is generally used as a PC marker (MacLennan et al., 2003). However, the distinction between PB and PCs in human blood based on CD138 is not obvious. $\mathrm{CD} 138^{+}$plasmablasts proliferate and express CD27 and CD38 at similar levels to $\mathrm{CD} 138^{-}$plasmablasts. Interestingly, both plasmablast subsets are induced similarly after vaccination with tetanus-, hepatitis A/B-, or influenza-vaccine (Qian et al., 2010). The CD27 $7^{\text {high }} \mathrm{CD} 19^{\text {low }} \mathrm{PB}$ population in peripheral blood contains subsets with high or low expression of cell proliferation-associated proteins (Yoshida et al., 2010), and CD $138^{+}$cells might represent re-circulating secondary lymphoid organs-derived PCs, or PB in an end-differentiation stage destined to become secondary lymphoid organ-resident PCs. Because of the diffuse transition from the $\mathrm{CD} 138^{-}$to the $\mathrm{CD} 138^{+}$ phenotype most studies do not differentiate between the two populations of cells and use the term antibody-secreting cells (ASC; Wrammert et al., 2008, 2012; He et al., 2011; Lee et al., 2011). The term acute plasmablasts will be used here to associate the $\mathrm{CD} 19^{\text {low }} \mathrm{CD} 20^{-} \mathrm{CD} 27^{\text {high }} \mathrm{CD} 38^{\text {high }} \mathrm{CD} 138^{+/}$cells appearing after infection with the acute phase of the immune response and to differentiate them from steady-state plasmablasts (Mei et al., 2009), although any potential functional or phenotypical differences have not been studied so far.

\section{TIMING OF PLASMABLAST APPEARANCE IN THE BLOOD}

The timing of acute PB appearance in the blood is strikingly consistent after immunization or infection: Flow cytometry analysis or ELISPOT performed ex vivo with human PBMCs sampled daily after vaccination with attenuated yellow fever strain YF-17D (Querec et al., 2009), inactivated influenza vaccine (Cox et al., 1994; Moldoveanu et al., 1995; Wrammert et al., 2008; Halliley et al., 2010; He et al., 2011), tetanus vaccine (Odendahl et al., 2005; Qian et al., 2010), and after infection with Respiratory Syncytial Virus (Lee et al., 2011) or dengue virus (Balakrishnan et al., 2011; Wrammert et al., 2012) showed that plasmablast numbers peak consistently at day 6 or 7 . The response thus seems to be independent of the adjuvant used and independent of the route of immunization. The appearance of $\mathrm{PB}$ in the blood is transient after vaccination (Odendahl et al., 2005; Lee et al., 2011) whereas the duration of the response depends on the persistence of the virus after natural infection. After infection with acute viruses such as influenza or dengue the PB numbers drop to baseline level within 2-3 weeks after the onset of disease (Balakrishnan et al., 2011; Wrammert 
Table 1 | Markers of infection-induced plasmablasts and plasma cells in human blood.

\begin{tabular}{|c|c|c|c|c|c|}
\hline Marker & Function & Memory B cells & Plasmablasts & Plasma cells & Reference \\
\hline CD19 & $\begin{array}{l}\text { Transmembrane signaling molecule; part of } \\
\text { BCR complex; regulating BCR signal }\end{array}$ & + & Low & Low & $\begin{array}{l}\text { Engel et al. (1995), Mei et al. (2007), Jacobi } \\
\text { et al. (2010) }\end{array}$ \\
\hline CD20 & $\begin{array}{l}\text { Transmembrane signaling molecule; part of } \\
\text { the BCR complex }\end{array}$ & + & - & - & $\begin{array}{l}\text { Arpin et al. (1997), Jacobi et al. (2010), } \\
\text { Kuijpers et al. (2010) }\end{array}$ \\
\hline CD27 & TNF receptor family & + & ++ & +++ & $\begin{array}{l}\text { Borst et al. (2005), Mei et al. (2007), Jacobi } \\
\text { et al. (2010) }\end{array}$ \\
\hline CD38 & $\begin{array}{l}\text { Signaling molecule and enzyme that cat- } \\
\text { alyzes the formation of cyclic ADP-ribose }\end{array}$ & $+1-$ & ++ & +++ & $\begin{array}{l}\text { Partida-Sanchez et al. (2001), Mei et al. } \\
\text { (2007) }\end{array}$ \\
\hline CD138 & Heparan sulfate proteoglycan; syndecan-1 & - & $+1-$ & + & Qian et al. (2010) \\
\hline Ki-67 & $\begin{array}{l}\text { Protein expressed intracellularly during cell } \\
\text { division }\end{array}$ & - & + & $+1-$ & $\begin{array}{l}\text { Wrammert et al. (2008), Qian et al. (2010), } \\
\text { Yoshida et al. (2010) }\end{array}$ \\
\hline
\end{tabular}

et al., 2012). Data from RSV-infected patients suggest that circulating PBs are produced as long as the virus is actively shed from infected cells (Lee et al., 2010). In contrast to the predictable time of appearance, mechanisms that determine the magnitude of the response seem to be more difficult to define: Data from vaccinees and from patients with natural viral infections show a huge variability in acute PB numbers between individuals, suggesting that the plasmablast response is governed by multiple factors.

The impact and requirement of $\mathrm{T}$ cell help is unclear. The acute $\mathrm{PB}$ responses observed after natural viral infection may differ in magnitude between primary and secondary infections, but the time of $\mathrm{PB}$ appearance in the circulation is similar, suggesting that pre-existing $\mathrm{T}$ cell help may not be required (Wrammert et al., 2008; Querec et al., 2009; Balakrishnan et al., 2011). However, it is difficult to exclude pre-existing immunity to viruses in endemic areas with absolute certainty, and therefore the comparison of primary versus secondary response is complex in the context of natural infections. In a controlled vaccination scenario, BlanchardRohner et al. (2009) demonstrate that the ASC response in naïve individuals peaks at day 10 after primary vaccination with inactivated rabies vaccine, whereas an accelerated response with a peak at day 7 is observed after booster vaccinations. Studies in mice show that specific $\mathrm{T}$ cell help promotes germinal center formation after viral infection, whereas absence of specific $\mathrm{T}$ cell help results in an increased extrafollicular response (Fink et al., 2007). PB formation in vitro is T-cell independent (Lane et al., 1995) and T cells can suppress the differentiation of memory B cell differentiation into PB in a CD40L-dependent manner (Arpin et al., 1995; Callard et al., 1995). Possibly the timing and T cell dependence of acute $\mathrm{PB}$ responses depends on the nature of the antigen and the engagement of pattern recognition receptors. In in vitro systems, TLR7 and 9 ligands are able to facilitate memory activation directly via TLR9 signaling in human memory B cells (Good et al., 2009) or indirectly via TLR7-mediated activation of dendritic cells in mice (Pordes et al., 2011) and via pDC-derived IFN-I in humans (Bekeredjian-Ding et al., 2005). It is thus possible that activation of memory B cells by viral infection is different from activation of memory B cells by recombinant vaccines. More studies in humans are required though to elucidate the mechanisms involved in $\mathrm{T}$ cell-dependent and -independent activation of acute PBs.

\section{ORIGIN OF ACUTE-PHASE PLASMABLASTS}

A recent study with HIV-infected persons on anti-retroviral treatment who were vaccinated with $\mathrm{H} 1 \mathrm{~N} 1$ vaccine and could be grouped into a responder and a non-responder group showed that the $\mathrm{PB}$ response at day 7 was predictive for the establishment of memory and for specific antibody titers at day 28. The study further showed that induction of $\mathrm{PB}$ and memory populations correlated with the capacity of B cells to upregulate IL-21 receptor, which differed in the responder- and non-responder group (Pallikkuth et al., 2011). In a Systems Biology approach Querec et al. (2009) found that TNFRSF17 expression in PBMCs collected at day 7 after yellow fever vaccination had the most predictive value for neutralizing antibody titers at day 28. Given the high expression of TNFRSF17 on PBs (Good et al., 2009) one could conclude that the magnitude of the $\mathrm{PB}$ response at day 7 is predictive for antibody titers at day 28. Given these lines of evidence that the early $\mathrm{PB}$ response may be predictive for later immunity, it is crucial to understand the origin(s) of plasmablasts in the context if a given antigen and adjuvant in order to specifically generate $\mathrm{B}$ cell subsets which can be triggered during repeated infection. Early in vitro experiments with human naïve and memory B cells from tonsils demonstrated that memory B cells differentiate faster and more efficiently into plasmablasts than naïve B cells after unspecific activation with CD40L and in the presence of IL-2 and IL-10 (Arpin et al., 1997). More recent studies using Ig sequencing of single plasma blasts and memory B cells to analyze their relation in the context of tetanus vaccination indicated that a given memory B cell precursor can give rise to plasma blasts and memory cells at the same time (Frolich et al., 2010). Other studies employing single cell PCR to analyze human cells after influenza infection showed that plasmablasts are more highly mutated than memory cells (Wrammert et al., 2008, 2011), suggesting that PB derive from memory cells that have undergone extensive selection and have possibly reached a threshold affinity required for their activation (O'Connor et al., 2006; Phan et al., 2006). Furthermore, steady-state PBs in the human gut are affinity matured and selected toward poly-reactivity and specificity for commensal bacteria (Benckert et al., 2011). All these data indicate that PBs circulating in the blood at day 6-7 after infection or immunization (acute PBs) are memory B cell-derived. The similar timing of the 
appearance of acute PBs after primary and booster immunization at least in the context of viral infections suggests that memory B cells can be the source of such PBs in both scenarios (Figure 1).

However, it needs to be shown which memory B cell subsets are involved and to which extent naïve B cells participate in the acute $\mathrm{PB}$ response. Influenza vaccine Fluzone, which is administered via the intradermal route, induces both IgA- and IgG-class-switched $\mathrm{PB}$ responses, while numbers of IgA-expressing cells are 10 times lower than the ones of IgG-expressing cells (Sasaki et al., 2011). Natural dengue infection induces specific IgA, IgG, and IgM PB (Wrammert et al., 2012). Our own studies show a consistent prevalence of IgA-producing cells (mean 65\%) in the acute PB population in the blood compared to only $2 \%$ IgA cells in the memory B cell pool in a cohort of patients with febrile illness caused by viral infections (unpublished data). Thus, a large part of the plasmablasts circulating during acute infection possibly derive from mucosal sites, similarly as in steady state (Mei et al., 2009). What is observed during infection could thus be an amplification of the steady state, with the difference that IgG-class-switched cells become a significant part of the response (Sasaki et al., 2011) possibly because more non-mucosal lymphoid organs (lymph nodes) participate in the response. During re-infection ( $2^{\text {ry }}$ response) the plasmablast response is dominated by $\operatorname{IgG}^{+}$PBs because of the formation of germinal centers in both non-mucosal and mucosal tissues and the generation of IgG-switched memory B cells between $1^{\text {ry }}$ and $2^{\text {ry }}$ infection (Figure 1 ).

\section{PREDICTIVE VALUE OF PLASMABLAST RESPONSES FOR IMMUNE MEMORY}

Recent systemic approaches to study immune responses after vaccinations in order to find parameters that are predictive of the long-term response have identified dominating plasma blast signatures in acute-phase (day 7) PBMC arrays (Querec et al., 2009; Nakaya et al., 2011). Natural viral infections can generate very impressive numbers of plasmablasts in the blood, as in the case of dengue virus infection (Balakrishnan et al., 2011; Wrammert

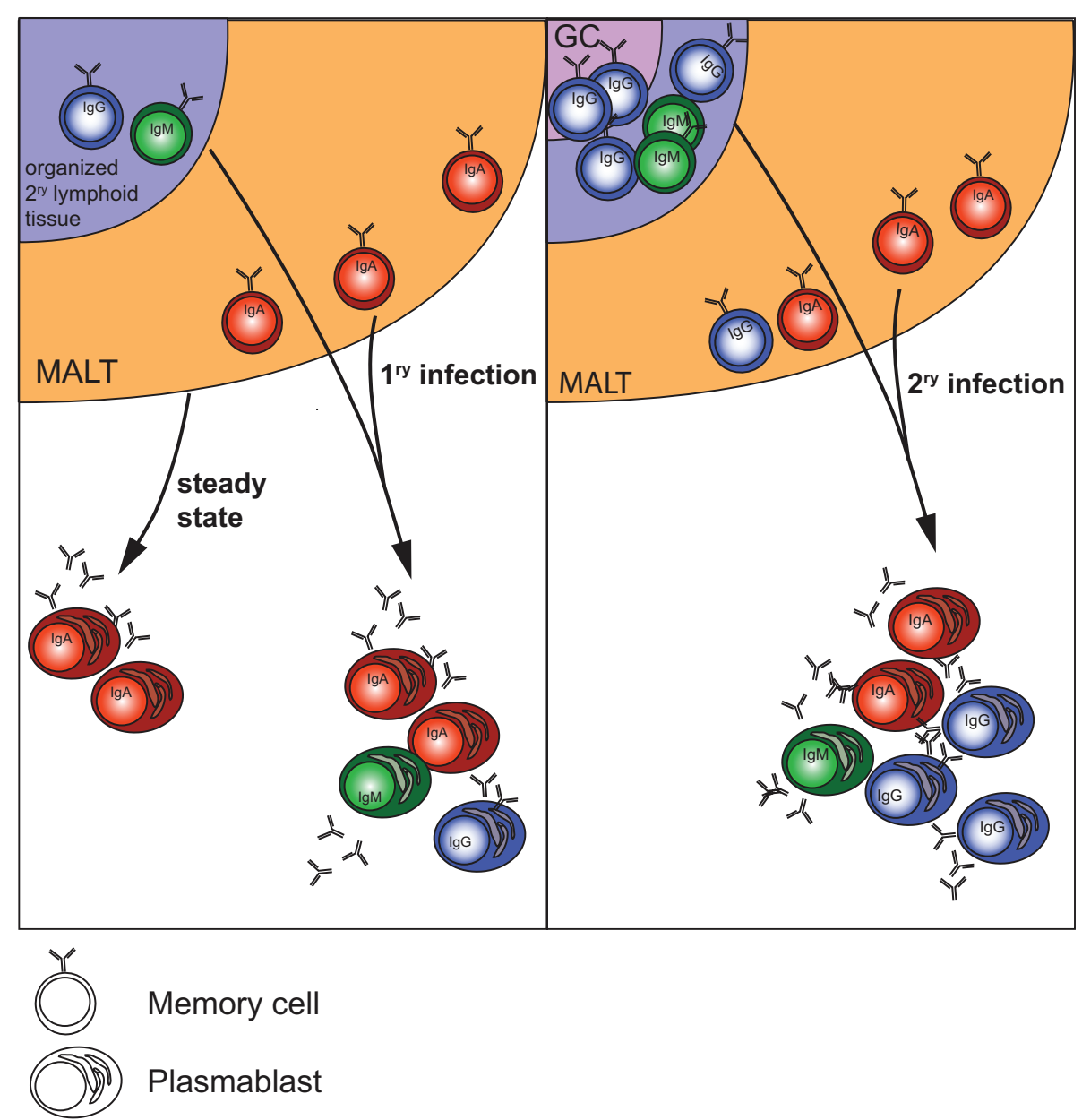

FIGURE 1 | Origin of plasmablasts in steady state and during $\mathbf{1}^{\text {ry }}$ and $2^{\text {ry }}$ infections in humans. During steady state, i.e., in healthy individuals the majority of plasmablasts in the circulation is $\lg \mathrm{A}^{+}$and is derived from mucosal immune responses (Mei et al., 2009). During systemic infection more $\mathrm{lgG}^{+}$cells from non-mucosal secondary lymphoid organs participate in the response. During repeated $\left(2^{\mathrm{ry}}\right)$ systemic infection with the same antigen a majority of the acute-phase plasmablasts are $\mathrm{lgG}^{+}$and derive from memory $\mathrm{B}$ cells, which have undergone class-switch and affinity maturation in germinal centers. 
et al., 2012). The important question remains what this means for protection and immune memory induction. Even though there might be some predictive value of the acute response for later protection (Querec et al., 2009) there are unsolved questions that need to be addressed. In the context of viral infections it is critical to analyze the antibody response beyond day 28 and to measure protective antibody titers by functional assays and B cell memory by ELISPOT. It is not known whether memory B cells can still provide protection once antibody titers fall below a protective threshold. Memory B cells might be particularly important when neutralizing antibody titers are insufficient to provide sterile protection. Rapid activation of memory B cells and their differentiation into antibody-secreting PBs might provide antibodies in quantities that can at least partially neutralize the virus and stop further dissemination in the organism. Indeed, the 6- to 7-day lag phase between memory B cell activation and plasma blast formation might be important to generate a minimal number of infected cells to trigger an effective $\mathrm{T}$ cell response, which will in turn help to boost and maintain B cell memory.

It is still unclear whether only a subset of B cells is triggered during an acute response or whether different $B$ cell subsets differ in their capacity to participate in the acute PB response. Moreover, in the context of long-lasting antibody titers in the

\section{REFERENCES}

Arpin, C., Banchereau, J., and Liu, Y. J. (1997). Memory B cells are biased towards terminal differentiation: a strategy that may prevent repertoire freezing. J. Exp. Med. 186, 931-940.

Arpin, C., Dechanet, J., Van Kooten, C., Merville, P., Grouard, G., Briere, F., Banchereau, J., and Liu, Y. J. (1995). Generation of memory B cells and plasma cells in vitro. Science 268, 720-722.

Balakrishnan, T., Bela-Ong, D. B., Toh, Y. X., Flamand, M., Devi, S., Koh, M. B., Hibberd, M. L., Ooi, E. E., Low, J. G., Leo, Y. S., Gu, F., and Fink, K. (2011). Dengue virus activates polyreactive, natural IgG $B$ cells after primary and secondary infection. PLoS ONE 6, e29430. doi:10.1371/journal.pone.0029430

Bekeredjian-Ding, I. B., Wagner, M., Hornung, V., Giese, T., Schnurr, M., Endres, S., and Hartmann, G. (2005). Plasmacytoid dendritic cells control TLR7 sensitivity of naive B cells via type I IFN. J. Immunol. 174, 4043-4050.

Benckert, J., Schmolka, N., Kreschel, C., Zoller, M. J., Sturm, A., Wiedenmann, B., and Wardemann, H. (2011). The majority of intestinal $\mathrm{IgA}+$ and $\mathrm{IgG}+$ plasmablasts in the human gut are antigen-specific. $J$. Clin. Invest. 121, 1946-1955.

Blanchard-Rohner, G., Pulickal, A. S., Jol-Van Der Zijde, C. M., Snape, M. D., and Pollard, A. J. (2009). Appearance of peripheral blood plasma cells and memory B cells in a primary and secondary immune response in humans. Blood 114, 4998-5002.

Borst, J., Hendriks, J., and Xiao, Y. (2005). CD27 and CD70 in T cell and $\mathrm{B}$ cell activation. Curr. Opin. Immunol. 17, 275-281.

Callard, R. E., Herbert, J., Smith, S. H., Armitage, R. J., and Costelloe, K. E. (1995). CD40 cross-linking inhibits specific antibody production by human B cells. Int. Immunol. 7, 1809-1815.

Cox, R. J., Brokstad, K. A., Zuckerman, M. A., Wood, J. M., Haaheim, L. R., and Oxford, J. S. (1994). An early humoral immune response in peripheral blood following parenteral inactivated influenza vaccination. Vaccine 12, 993-999.

Engel, P., Zhou, L. J., Ord, D. C., Sato, S., Koller, B., and Tedder, T. F. (1995). Abnormal B lymphocyte development, activation, and differentiation in mice that lack or overexpress the CD19 signal transduction molecule. Immunity 3, 39-50.

Fink, K., Manjarrez-Orduno, N., Schildknecht, A., Weber, J., Senn, B. M., Zinkernagel, R. M., and Hengartner, H. (2007). B cell activation state-governed formation of germinal centers following viral infection. J. Immunol. 179, 5877-5885.

Frolich, D., Giesecke, C., Mei, H. E., Reiter, K., Daridon, C., Lipsky, P. E., and Dorner, T. (2010). Secondary

blood and the maintenance of memory B cells, it is not known whether siblings of acute, short-lived PBs can become long-lived PCs. A recent study in mice showed that memory B cell-derived antibodies could neutralize an escape variant of West Nile virus whereas bone marrow-derived PCs could only neutralize the original virus (Purtha et al., 2011). Moreover, human HIV-specific memory B cells were recently shown to derive from polyclonal memory B cells (Liao et al., 2011). It seems thus likely that not only naïve B cells, but also memory B cells are engaged in primary responses or in responses against virus variants. The potential capacity of relatively unspecific memory B cells to further affinity-mature and adapt may thus be important for vaccinations, particularly in adults, since highly affinity matured B cells can efficiently differentiate into plasmablasts. More studies on the re-engagement of memory B cells during persistent viral infections or during re-infection with acute virus variants are required to understand the relevance and potential impact of this type of immune response, and to assess its predictive value for immune memory.

\section{ACKNOWLEDGMENTS}

This work was funded by the Agency for Science, Technology and Research (A*STAR), Singapore.

immunization generates clonally related antigen-specific plasma cells and memory B cells. J. Immunol. 185, 3103-3110.

Good, K. L., Avery, D. T., and Tangye, S. G. (2009). Resting human memory $B$ cells are intrinsically programmed for enhanced survival and responsiveness to diverse stimuli compared to naive B cells. J. Immunol. 182, 890-901.

Halliley, J. L., Kyu, S., Kobie, J. J., Walsh, E. E., Falsey, A. R., Randall, T. D., Treanor, J., Feng, C., Sanz, I., and Lee, F. E. (2010). Peak frequencies of circulating human influenzaspecific antibody secreting cells correlate with serum antibody response after immunization. Vaccine 28, 3582-3587.

He, X. S., Sasaki, S., Narvaez, C. F., Zhang, C., Liu, H., Woo, J. C., Kemble, G. W., Dekker, C. L., Davis, M. M., and Greenberg, H. B. (2011). Plamablast-derived polyclonal antibody response after influenza vaccination. J. Immunol. Methods 365, 67-75.

Jacobi, A. M., Mei, H., Hoyer, B. F., Mumtaz, I. M., Thiele, K., Radbruch, A., Burmester, G. R., Hiepe, F., and Dorner, T. (2010). HLA-DRhigh/CD27high plasmablasts indicate active disease in patients with systemic lupus erythematosus. Ann. Rheum. Dis. 69, 305-308.

Jego, G., Bataille, R., and PellatDeceunynck, C. (2001)
Interleukin-6 is a growth factor for nonmalignant human plasmablasts. Blood 97, 1817-1822.

Kuijpers, T. W., Bende, R. J., Baars, P. A., Grummels, A., Derks, I. A., Dolman, K. M., Beaumont, T., Tedder, T. F., Van Noesel, C. J., Eldering, E., and Van Lier, R. A. (2010). CD20 deficiency in humans results in impaired $\mathrm{T}$ cell-independent antibody responses. J. Clin. Invest. 120, 214-222.

Lane, P., Burdet, C., Mcconnell, F., Lanzavecchia, A., and Padovan, E. (1995). CD40 ligand-independent $B$ cell activation revealed by CD40 ligand-deficient $\mathrm{T}$ cell clones: evidence for distinct activation requirements for antibody formation and B cell proliferation. Eur. J. Immunol. 25, 1788-1793.

Lee, F. E., Falsey, A. R., Halliley, J. L., Sanz, I., and Walsh, E. E. (2010). Circulating antibodysecreting cells during acute respiratory syncytial virus infection in adults. J. Infect. Dis. 202, 1659-1666.

Lee, F. E., Halliley, J. L., Walsh, E. E., Moscatiello, A. P., Kmush, B. L., Falsey, A. R., Randall, T. D., Kaminiski, D. A., Miller, R. K., and Sanz, I. (2011). Circulating human antibody-secreting cells during vaccinations and respiratory viral infections are characterized by high specificity and lack of bystander effect. J. Immunol. 186, 5514-5521. 
Liao, H. X., Chen, X., Munshaw, S., Zhang, R., Marshall, D. J., Vandergrift, N., Whitesides, J. F., Lu, X., Yu, J. S., Hwang, K. K., Gao, F., Markowitz, M., Heath, S. L., Bar, K. J., Goepfert, P. A., Montefiori, D. C., Shaw, G. C., Alam, S. M., Margolis, D. M., Denny, T. N., Boyd, S. D., Marshal, E., Egholm, M., Simen, B. B., Hanczaruk, B., Fire, A. Z., Voss, G., Kelsoe, G., Tomaras, G. D., Moody, M. A., Kepler, T. B., and Haynes, B. F. (2011). Initial antibodies binding to HIV-1 gp41 in acutely infected subjects are polyreactive and highly mutated. J. Exp. Med. 208, 2237-2249.

MacLennan, I. C., Toellner, K. M., Cunningham, A. F., Serre, K., Sze, D. M., Zuniga, E., Cook, M. C., and Vinuesa, C. G. (2003). Extrafollicular antibody responses. Immunol. Rev. 194, 8-18.

Mei, H. E., Yoshida, T., Muehlinghaus, G., Hiepe, F., Dorner, T., Radbruch, A., and Hoyer, B. F. (2007). Phenotypic analysis of B-cells and plasma cells. Methods Mol. Med. 136, 3-18.

Mei, H. E., Yoshida, T., Sime, W., Hiepe, F., Thiele, K., Manz, R. A., Radbruch, A., and Dorner, T. (2009). Blood-borne human plasma cells in steady state are derived from mucosal immune responses. Blood 113, 2461-2469.

Moldoveanu, Z., Clements, M. L., Prince, S. J., Murphy, B. R., and Mestecky, J. (1995). Human immune responses to influenza virus vaccines administered by systemic or mucosal routes. Vaccine 13, 1006-1012.

Nakaya, H. I., Wrammert, J., Lee, E. K., Racioppi, L., Marie-Kunze, S., Haining, W. N., Means, A. R., Kasturi, S. P., Khan, N., Li, G. M., Mccausland, M., Kanchan, V., Kokko, K. E., Li, S., Elbein, R., Mehta, A. K., Aderem, A., Subbarao, K., Ahmed, R., and Pulendran, B. (2011). Systems biology of vaccination for seasonal influenza in humans. Nat. Immunol. 12, 786-795.

O'Connor, B. P., Vogel, L. A., Zhang, W., Loo, W., Shnider, D., Lind, E. F., Ratliff, M., Noelle, R. J., and Erickson, L. D. (2006). Imprinting the fate of antigen-reactive B cells through the affinity of the B cell receptor. $J$. Immunol. 177, 7723-7732.

Odendahl, M., Mei, H., Hoyer, B. F., Jacobi, A. M., Hansen, A. Muehlinghaus, G., Berek, C., Hiepe, F., Manz, R., Radbruch, A., and Dorner, T. (2005). Generation of migratory antigen-specific plasma blasts and mobilization of resident plasma cells in a secondary immune response. Blood 105, 1614-1621.

Pallikkuth, S., Pilakka Kanthikeel, S., Silva, S. Y., Fischl, M., Pahwa, R., and Pahwa, S. (2011). Upregulation of IL-21 receptor on B cells and IL-21 secretion distinguishes novel $2009 \mathrm{H} 1 \mathrm{~N} 1$ vaccine responders from nonresponders among HIV-infected persons on combination antiretroviral therapy. J. Immunol. 186, 6173-6181.

Partida-Sanchez, S., Cockayne, D. A., Monard, S., Jacobson, E. L., Oppenheimer, N., Garvy, B., Kusser, K., Goodrich, S., Howard, M., Harmsen, A., Randall, T. D., and Lund, F. E. (2001). Cyclic ADP-ribose production by CD38 regulates intracellular calcium release, extracellular calcium influx and chemotaxis in neutrophils and is required for bacterial clearance in vivo. Nat. Med. 7, 1209-1216.

Phan, T. G., Paus, D., Chan, T. D., Turner, M. L., Nutt, S. L., Basten, A., and Brink, R. (2006). High affinity germinal center $\mathrm{B}$ cells are actively selected into the plasma cell compartment. J. Exp. Med. 203, 2419-2424.

Pordes, A. G., Baumgartner, C. K., Allacher, P., Ahmad, R. U., Weiller, M., Schiviz, A. N., Schwarz, H. P., and Reipert, B. M. (2011). T cellindependent restimulation of FVIIIspecific murine memory $B$ cells is facilitated by dendritic cells together with toll-like receptor 7 agonist. Blood 118, 3154-3162.

Purtha, W. E., Tedder, T. F., Johnson, S., Bhattacharya, D., and Diamond, M. S. (2011). Memory B cells, but not long-lived plasma cells, possess antigen specificities for viral escape mutants. J. Exp. Med. 208, 2599-2606.
Qian, Y., Wei, C., Eun-Hyung Lee, F., Campbell, J., Halliley, J., Lee, J. A., Cai, J., Kong, Y. M., Sadat, E., Thomson, E., Dunn, P., Seegmiller, A. C. Karandikar, N. J., Tipton, C. M. Mosmann, T., Sanz, I., and Scheuermann, R. H. (2010). Elucidation of seventeen human peripheral blood B-cell subsets and quantification of the tetanus response using a densitybased method for the automated identification of cell populations in multidimensional flow cytometry data. Cytometry B Clin. Cytom. 78(Suppl. 1), S69-S82.

Querec, T. D., Akondy, R. S., Lee, E. K., Cao, W., Nakaya, H. I., Teuwen, D., Pirani, A., Gernert, K., Deng, J., Marzolf, B., Kennedy, K., Wu, H., Bennouna, S., Oluoch, H., Miller, J., Vencio, R. Z., Mulligan, M., Aderem, A., Ahmed, R., and Pulendran, B. (2009). Systems biology approach predicts immunogenicity of the yellow fever vaccine in humans. Nat. Immunol. 10, 116-125.

Sasaki, S., Sullivan, M., Narvaez, C. F., Holmes, T. H., Furman, D., Zheng, N. Y., Nishtala, M., Wrammert, J., Smith, K., James, J. A., Dekker, C. L., Davis, M. M., Wilson, P. C., Greenberg, H. B., and He, X. S. (2011). Limited efficacy of inactivated influenza vaccine in elderly individuals is associated with decreased production of vaccinespecific antibodies. J. Clin. Invest. 121, 3109-3119.

Wrammert, J., Koutsonanos, D., Li, G. M., Edupuganti, S., Sui, J., Morrissey, M., Mccausland, M., Skountzou, I., Hornig, M., Lipkin, W. I., Mehta, A., Razavi, B., Del Rio, C., Zheng, N. Y., Lee, J. H., Huang, M., Ali, Z., Kaur, K., Andrews, S., Amara, R. R., Wang, Y., Das, S. R., O’Donnell, C. D., Yewdell, J. W., Subbarao, K., Marasco, W. A., Mulligan, M. J., Compans, R., Ahmed, R., and Wilson, P. C. (2011). Broadly cross-reactive antibodies dominate the human $\mathrm{B}$ cell response against 2009 pandemic H1N1 influenza virus infection. J. Exp. Med. 208, 181-193.

Wrammert, J., Onlamoon, N., Akondy, R. S., Perng, G. C., Polsrila, K., Chandele, A., Kwissa, M., Pulendran,
B., Wilson, P., Wittawatmongkol, O., Yoksan, S., Angkasekwinai, N., Pattanapanyasat, K., Chokephaibulkit, K., and Ahmed, R. (2012). Rapid and massive virus specific plasmablast responses during acute dengue virus infection in humans. J. Virol. 86, 2911-2918.

Wrammert, J., Smith, K., Miller, J., Langley, W. A., Kokko, K., Larsen, C., Zheng, N. Y., Mays, I., Garman, L., Helms, C., James, J., Air, G. M., Capra, J. D., Ahmed, R., and Wilson, P. C. (2008). Rapid cloning of high-affinity human monoclonal antibodies against influenza virus. Nature 453, 667-671.

$\mathrm{Wu}$, Y.-C. B., Kipling, D., and Dunn-Walters, D. K. (2011). The relationship between $\mathrm{CD} 27$ negative and positive $B$ cell populations in human peripheral blood. Front. Immunol. 2:81. doi:10.3389/fimmu.2011.00081

Yoshida, T., Mei, H., Dorner, T., Hiepe, F., Radbruch, A., Fillatreau, S., and Hoyer, B. F. (2010). Memory B and memory plasma cells. Immunol. Rev. 237, 117-139.

Conflict of Interest Statement: The author declares that the research was conducted in the absence of any commercial or financial relationships that could be construed as a potential conflict of interest.

Received: 02 February 2012; paper pending published: 21 February 2012; accepted: 27 March 2012; published online: 17 April 2012.

Citation: Fink K (2012) Origin and function of circulating plasmablasts during acute viral infections. Front. Immun. 3:78. doi: 10.3389/fimmu.2012.00078 This article was submitted to Frontiers in B Cell Biology, a specialty of Frontiers in Immunology.

Copyright (C) 2012 Fink. This is an openaccess article distributed under the terms of the Creative Commons Attribution Non Commercial License, which permits non-commercial use, distribution, and reproduction in other forums, provided the original authors and source are credited. 